Contemporary public perceptions of nursing: a systematic review and narrative synthesis of the international research evidence

Professor June GIRVIN RN MSc

Pro Vice-Chancellor and Dean

Faculty of Health and Life Sciences

Oxford Brookes University

Email: jgirvin@brookes.ac.uk

Tel: 01865484099 or 01865482560

Professor Debra JACKSON RN, PhD

Professor of Nursing, Faculty of Health \& Life Sciences, Oxford Brookes University Associate Chief Nurse (Research), Oxford University Hospitals NHS Foundation Trust, UK. Professor of Nursing, University of New England

Oxford OX3 OFL

United Kingdom

Email: djackson@brookes.ac.uk

Dr Marie HUTCHINSON RN, RM PhD

Visiting research fellow, Oxford Brookes University

Associate Professor, Southern Cross University

School of Health \& Human Sciences PO Box 157,

Lismore NSW 2480 Australia

Email: marie.hutchinson@scu.edu.au

Statement of funding: This project was funded by a grant from Oxford Brookes University central research funds.

\title{
Acknowledgement
}

The authors acknowledge the assistance of Angela Halpen, Oxford Brookes University who assisted with identifying and gathering literature. 


\section{Contemporary public perceptions of nursing: a systematic review and narrative synthesis of the international research evidence}

\section{Abstract}

Aim

To investigate current public understanding and perceptions of nursing.

\section{Background}

In recent years, attention to large scale health care failures has focused considerable concern upon nursing standards. To avoid short-term solutions, and the temptation to see individual failures as representative of the wider profession, it is important to understand contemporary public perceptions of nursing.

\section{Evaluation}

A systematic review and narrative synthesis of peer reviewed papers January 2010 to September 2015.

Key issues Four main themes were identified: i) media portrayal of nursing as a troubled profession; ii) entertainment value in demeaning nursing; iii) role incongruity - nursing trusted but not respected; and iv), nursing roles remain poorly understood.

Conclusions Though there is evidence of strong public trust, this does not generally appear to be born out of an understanding of nursing work and impact; rather it appears to stem from the respect held for the traditional, more sentimental stereotypes of selfless, hardworking young females.

Implications for nursing management A long-term, strategic solution is required which focuses on public engagement and interaction with the profession in a wider context than personal health/ill-health, and that go beyond the marketing campaigns seen in the past to address recruitment crises.

Keywords: public perception, nursing, media image, pubic knowledge, public opinion, nursing workforce 


\section{Introduction}

What nurses do and the impact that nursing has upon patients and clients is increasingly researched and documented. Findings from this body of work have helped to establish high quality, degree-level preparation, and has also demonstrated the importance of continuing, career-long education and development within the profession. However, the prevailing public discourse around nursing lags well behind this progressive curve. As Shields (2012) has noted, there has been little shift in the public view from the stereotypes of 'heroine, harlot, harridan or handmaiden' and these stereotypes are repeatedly played out in fictional accounts of nurses and nursing. These gendered and inaccurate images and representations of nursing limit public understanding of nurses as knowledgeable and skilled health care professionals (Donelan et al., 2008).

A number of previous studies have examined perceptions of nurses and nursing students' image of nursing and professional identity (Johnson et al. 2012). Reviewing this body of work it has been reported that, in part, nurses derive their professional identity from their public image (Hoeve, Jansen et al. 2014) and the pathway to formation of this professional identity begins prior to beginning nursing education. In light of the persistently poor and limited portrayals of nursing available to them, talented students are reported to be less likely to select nursing as a career (Miller \& Cummings 2009). Thus, images of nursing are likely to impact upon nursing as a career choice, with negative images exacerbating workforce recruitment issues. Though the link between professional image and workforce recruitment and retention is yet to be empirically established (Cho et al. 2010, Johnson et al. 2012,), negative images and perceptions of nursing are likely to limit consideration of nursing as a career choice.

Beyond nurses' views, it is necessary to critically consider public perceptions of nursing. Less attention has been given to systematically reviewing evidence about what the public understand about nursing and their image of nursing. In the 2013 literature review conducted by Hoeve, Jansen and Roodbol (2014) the depiction of nurses in the media was examined but consideration was not given to studies relating to broader public perceptions of nursing. Reports suggest that in an international context, public perceptions of nursing are paradoxical. In the United Kingdom research has shown that parents and career 
advisors are less likely to encourage school leavers to consider nursing as a career choice (Neilson \& McNally, 2013), whereas a survey of public perception of nursing conducted in the United States reported that nursing is highly respected and the majority of the public viewed and would recommend nursing as a career (Donelan et al. 2008).

In recent years the perception of nursing as a troubled profession (Girvin, 2015) has been magnified by reports into health care failures (Francis 2010, Keogh 2013), and by publicity and concern around nursing shortages. This growing concern has publicly positioned nursing in terms of deficit, sustaining what Donley (2005) has described as a 'negative affectivity' about nursing. Reflecting this negative affectivity, stories of what is wrong with nursing outweigh those about what is right and good. This has been increasingly apparent around debate on nursing in the UK, with media denigration of degree preparation for nursing making unfavourable comparisons between 'modern' nurses and those from the 'Golden Age' of the 1950s, 60s and 70s. In an era when how - and by whom - health care is delivered is a major pre-occupation, public understanding of nursing is stubbornly and unhelpfully nostalgic. Such views fail to understand the nature of $21^{\text {st }}$ century health care, and the significant contribution that nurses make.

In this paper we aim to review the current research literature on public understanding of nursing and nursing's image to identify if there is any substantive data that may begin to refute these long-held nostalgic views and underpin a new conception of nursing for the $21^{\text {st }}$ century. This paper examines the characteristics of the public image of nursing over a five year period. In light of contemporary, debates (see for example: IOM, 2010; Francis 2010; HHE, 2015; Willis 2015), we were particularly interested to capture the nature of public perceptions during this period.

\section{The review}

\section{Aims}

This systematic review aimed to explore current public understanding and/or perception of nursing. To identify contemporary evidence on this, the review included primary research studies and structured literature reviews that reported perceptions of 
members of the public, as well as representations of nursing in newsprint, social media and film.

\section{Search strategy}

The search was performed in collaboration with a health and social care librarian to ensure rigour and eliminate risk of bias. Initially the search strategy was tested to verify that the terms would locate appropriate literature. The following databases were chosen based on relevance to the subject matter; CINAHL, British Nursing Index (BNI), PubMed and PyschInfo. The search terms (see Table 1) were chosen based on a review of MeSH terms and CINAHL headings with synonyms employed to provide an efficient search strategy. The period for the search was between 2010 and 2015. The primary research filter was applied where available (CINAHL and Psychinfo). Articles that were not written in English or were duplicated were removed. Excluded from the review were opinion pieces, discursive literature reviews and editorials.

\section{Inclusion criteria}

All the authors of this study participated in the process of reading and screening the manuscripts. To be included in the review, studies had to meet the following inclusion criteria: (1) focused on public perceptions of nursing, or reporting public images of nursing or perceptions about nursing roles; (2) published in 2010 through to September 2015; (3) published in English; and (4) peer-reviewed with full text available. We included descriptive and observational studies as well as studies of secondary data sources such as newspaper articles, social media, webpages and film. As we were interested in public understanding and perceptions of nursing we excluded studies where nurses or nursing students reported their views on the public understanding and perception of nursing; as were studies of midwifery. Multiple publications reporting components of the same data were included in the review as one study.

\section{Search outcome}

Following the initial search, a total of 777 manuscripts were retrieved across the databases. The results from each database are summarised in Table 1. Initially results were screened by title and discarded if there was no connection to public perceptions, 
understanding or opinions of nursing or the image of nursing. The remaining 82 abstracts were reviewed, after which 30 were discarded as they did not meet the search criteria. These manuscripts were not research based and focused on perceptions about a certain illness either by nurses or an identified group, public health issues, specific job roles or specialist categories of nurse, and literature reviews. Full copies of the retained manuscripts were retrieved for review. Subsequently, 32 manuscripts were removed as they focused upon professional status, inter-professional relationships, nurses' or nursing students' perspectives rather than public opinion, or midwifery. Two papers were identified from citation analysis and a Google search identified two further papers, neither of which was retained after full text review.

The final number of manuscripts retained was twenty two; two reported the same study, bringing our final count down to 21 studies. The included studies were not homogenous with respect to design, sample and setting and were unsuited to meta-analysis.

\section{Data extraction}

Standardised data extraction from retained papers was undertaken to derive an evidence table detailing authors, country, participants, sample, study design and study findings (Table 1) (Harbour \& Miller 2001). The significant results from each study were also extracted employing keyword or concept identification and complied in a spreadsheet. Systematic coding of the extracted content of the included studies was followed by clustering and condensing of codes into themes to derive an integrated synthesis.

\section{Synthesis}

Themes were identified in the data extracted from the manuscripts by noting similarities and clustering the extracted data to derive a synthesised interpretation. This method of narrative analysis was chosen as it suited the numerical and narrative data methods of the studies reviewed. Data extraction and coding was initially performed by one of the authors, after which, each author reviewed the synthesis and the accuracy of data extraction 


\section{Results}

\section{Overview of included studies}

The majority of the studies in the final inclusion group were data-based studies, one was a concept analysis derived from published literature (Rezaei-Adaryani et al. 2012). The papers included studies spanning the period between 2010 and 2015. Two studies were described as discourse analyses (Gillett 2014, Kelly et al. 2012), eight employed surveys (Allnutt et al. 2010, Ben Natan \& Becker 2010, Van Tonder \& Neltjjie 2011, Wilson et al. 2012, Ben Natan et al. 2013,Meiring \& Van Wyk 2013, Keçeci et al. 2014, Keçeci et al. 2014 ). Four employed qualitative interview or focus groups (Morris-Thompson et al. 2011, Neilson \& McNally 2010, Neilson and McNally 2013, Norman 2015, Lasiter \& McLennon 2015), the remaining studies employed qualitative analysis of published media and film. Other types of studies analysed in the review were film Stanley, D., 2012; websites (Boyle, 2010); newspaper reports (Miller, et al., 2012Gillett, K. 2014, Van Zyl \& Christofides 2014, social media (Kelly et al. 2012, Hutchinson and Jackson 2014); literature and historical documents (Brideson, 2015).

\section{Quality of the studies included}

The validated Mixed Methods Appraisal Tool (MMAT) was employed to appraise the quality of the studies included in the review (Pace et al. 2012). The tool contains three sets of review criteria (quantitative, qualitative or mixed methods) and studies were scored yes or no against each criteria. Two members of the team undertook the quality reviews independently, and results were cross checked. The frequency of yes/no responses are reported for each criteria in Table 3. This table allows for comparison of lower and higher MMAT scores on for each criterion and the identification of limitations across the set of quantitative, qualitative or mixed methods. The more common limitations identified for the qualitative studies in the review included poor description of study participants, limited discussion of data collection and analysis, and no description of researcher reflexivity. For the quantitative studies, sample generation and recruitment, along with justification of the validity or reliability of measurement tools were the criteria rated poorly.

\section{Emergent themes}


Four main themes and constituent sub-themes were identified from the analysis: i) media portrayal of nursing as a troubled profession; ii) entertainment value in demeaning nurses; iii) positive public perceptions, but nursing roles are poorly understood; and iv) nursing as a low-image profession .

\section{Media portrayal of nursing as a troubled profession}

For the period included in our analysis, prominent in social media and newsprint were stories about perceived failures of nursing care. Although there were some reports that were positive towards nursing (Brideson, 2015), and instances of reported good practice that were more likely to be reported by community newspapers (Zyl \& Christofides 2014), the public discourses in the media were primarily focused upon: perceptions of care failure; nurses as unprofessional (Zyl \& Christofides 2014); militant; or nurses as over educated and failing to care (Miller et al. 2012, Gillett 2014, Zyl \& Christofides 2014, Hutchinson \& Jackson 2014).

In particular, studies from the UK (Gillett, 2014; Hutchinson \& Jackson 2014) portrayed a discourse of nursing as a 'troubled profession' (Girvin 2015). Analysis of public discourses during particular high-profile public events, such as the transition period of nursing in the UK to the higher education sector (Gillett 2014) and the Care Quality Commission (CQC) report into hospital inspections in the UK, National Health Service (NHS) (Hutchinson \& Jackson 2014) reflected a view that there was little that was positive in nursing. Similarly, the analysis of 1704 newspaper articles about nursing homes undertaken over a ten year period identified very few stories that were positive $(9.6 \%)$, with the majority focused upon care quality failures, financing and negligence (Miller et al. 2012). One study reporting primarily positive media images of nursing reported that more than $50 \%$ of the 242 newspaper articles analysed presented positive images of nursing (Van Zyl \& Christofides 2014).

\section{Entertainment value in demeaning nursing}

Gender prejudices remain prevalent in public images of nursing, and these prejudices were evidenced in portrayals of nurses characterised as sexual playthings (Kelly et al. 2012, Keçeci et al. 2014), beautiful young and sexy, defying danger to find romance 
(Bridesom et al., 2015), sexually deviant (Neilson and McNally 2013, Stanley 2013) and male nurses characterised as effeminate or aberrant homosexuals (Stanley 2013). It was evident that there is entertainment value in demeaning nursing and nurses in film and social media, with hostile interpretations of nursing depicted as entertainment.

In film and social media, attractive, successful, intelligent and educated women were positioned as incompatible with nursing (Kelly et al. 2012, Neilson and McNally 2010, Neilson and McNally 2013). Similarly, masculinity was viewed as inconsistent with nursing (Stanley 2013). Male nurses in film were portrayed in nursing roles traditionally seen as the domain of women (midwifery, palliative care), alternatively male nurses were portrayed as morally corrupt, effeminate, incompetent; or were framed in sexualised terms or as underachievers who were not capable of teaching or medicine (Stanley, 2013).

Images of nursing as a troubled profession were also overlaid with hostile sexism. Interpreted through this lens, media portrayals of nursing during the period of transition of nursing to the higher education sector in the UK (Gillett 2014) were largely negative, hostile and gendered. Gillet (2014) reported that during this period, $68 \%$ of media reports portrayed a negative image of nursing. The narratives were overtly gendered with reference to nurses as women who were 'born to salvation' and did not expect to be 'paid lavishly'. These narratives invoked a return to the 'past' or a 'golden era' where nurses were not well-educated (Gillett 2014) with reference to nursing being 'removed', 'put back' and 'returned' to a lower-educated status.

\section{Positive public perceptions, but nursing roles are poorly understood}

It was evident from the analysis that public perceptions about nursing varied according to the source. As highlighted in Table 4, the majority of studies employing samples from the general public reported largely positive perceptions about nursing, while media portrayals were predominately negative.

The study by Wilson and colleagues reported mixed findings on public perceptions of chronic disease nurse specialists (Wilson et al. 2012). The service users in this study valued nurses who practiced autonomously and fulfilled roles such as independent prescribing, 
with a number of respondents viewing nurse specialists as more knowledgeable than General Practitioners, highly visible and their first point of contact (Wilson et al. 2012). However, in the same study, other respondents interpreted nursing roles through a relationship to medicine, with nurses positioned as apprentices to doctors (Wilson et al. 2012). In the Australian study by Allnutt and colleagues (2010), while perceptions of nursing were largely positive, clients who consulted Nurse Practitioners (NP) were unable to differentiate between different categories of Registered Nurse and, although many had previously heard about NPs, the majority were uncertain about the scope of the NP role, could not differentiate the function of NPs from doctors, and were unclear about NP specialist education requirements.

School children were reported to have little understanding of community nursing, with nursing considered to require lower levels of academic achievement (Norman 2015). A data-based study identified nursing as underrepresented in health service web pages and public web sites offering critical information to patients with cancer and their families. The absence of nursing in these web sites was contrasted with the dominance of medicine particularly the depiction of physicians as being the hub of all care or treatment. Interestingly, although numerous other disciplines were listed on the web sites, 10 of them had no nursing descriptors, and just 9 had a listing for the nursing department but no role specific information (Boyle 2010).

\section{Nursing as a low-image profession}

The perception of nursing as a low-image career choice and unsuitable career was reported in studies from Israel, Scotland, England, and South Africa. In these studies, adults and secondary school students reported that they were unlikely to choose nursing as a career (Ben Natan and Becker 2010, Morris Thompson et al. 2011, Neilson and McNally 2013, Norman 2015). In the majority of studies, nursing was characterised as a career that was not interesting or 'stretching', that lacked challenge, creativity, and responsibility, or that had few opportunities for promotion or creativity (Ben Natan and Becker 2010). In one study nursing was perceived to be comparable to office work or hairdressing (Neilson and McNally 2013). Additionally, nursing was not viewed as an ideal career by school career 
advisors, and few family members would recommend nursing as a career to their relatives (Ben Natan and Becker 2010).

In a similar vein, images of nurses as leaders or influencing important decision making was absent from media portrayals of nursing. The public rarely identified nursing in leadership roles, and US industry leaders perceived nurses as having a low degree of influence over health care reform (Khoury et al, 2011). Although these industry leaders did report favourable perceptions about nursing, pointing to the key influence of nursing in averting errors and improving care safety and quality (Khoury et al, 2011) which resonates with an earlier report from the United States (Donelan et al. 2008).

\section{Discussion}

Our review findings suggest that both the volume and nature of studies on public perceptions of nursing have changed considerably over the last decade. An earlier systematic review undertaken by Hoeve, Jansen et al., (2014) for a fifteen year period (1997-2010) identified six studies garnering views directly from the public about nursing. In contrast, in the five year period of our analysis there were 13 studies canvassing views directly from the public. This suggests there has been a six fold increase in nursing studies directly engaging with the public about their perceptions and understanding of nursing. This highlights a shift from nurses talking among themselves about public perceptions and the image of nursing, towards a broader discourse informed through public engagement.

A number of the broad themes identified from our analysis resonate with previous research on the public image of nursing (Kalisch \& Kalisch 1983, Hoeve, Jansen et al 2014, Gillet 2014). In many countries, the media have played an important role in raising concerns about care standards. Lloyd and colleagues analysed media reporting and subsequent policy responses to nursing home scandals in Canada, Norway, Sweden, the United Kingdom and the United States of America (Lloyd et al. 2014). They note that the media played an important role in spotlighting the scope of care failures and some of the contributory factors. Nonetheless, it is important for attention to be given to how the media frames problems and how these images are likely to negatively influence public perceptions about nursing - particularly when it frames nursing as a profession undeserving of public respect. 
Media portrayals about what is wrong with nursing far outweigh public discourses about what is positive and beneficial. Donelan (2008) has previously noted how these unfavourable reports shape public views and affectivity about nursing and nurses. Our analysis confirms that the issues most likely to be reported in the media are scandals or other untoward events. A previous concept analysis reported that negative images portrayed in the media influence nurses' reluctance to speak to the media (Ezaeia-Daryani et al 2012). Moreover, the gendered and aggressive tone of much of the newspaper and social media reporting and commentary on nursing resonates with reports of gendered, sexualised and demeaning verbal violence nurses experience in their workplaces (Jackson et al. 2013, Spector et al. 2014, Somani et al. 2015). None of this is conducive to nurses developing the confidence to speak out about what it is that nurses do and the differences nurses can make.

It was evident from the studies in our review that hostile sexism towards nursing (most often expressed in media and film portrayals) were related to negative views of the emergence of non-traditional nursing roles and progress in the discipline. Media debate on the transfer of nursing to the higher education sector in the UK sharply focused public perceptions on historical interpretations of nursing as a gendered and less educated profession. The move of nurses to occupy academically qualified roles, which had traditionally been the domain of men (and medicine), was incongruous to public perceptions of nursing. Because of this incongruity, in the media nurses were viewed less favourably, which in some countries fostered an outpouring of prejudice and hostile sexism (Zhuge et al. 2011). This is similar to previous research that has found hostile sexism is related to more negative views of women when they occupy non-traditional roles (Clow and Ricciardelli 2011). Predominately negative media reporting about nursing not only contributes to a poor public image of the profession, but by association, also of the individuals who choose to become nurses.

Public perceptions about nursing were also linked to public understandings of what nurses do, the social status of nursing work, and whether nursing was interpreted through a subordinate relationship to medicine which reinforced traditional views about power and 
the nature of nursing work (Wilson et al. 2012). The lack of public esteem for nursing, together with perceptions about the nature of the nursing work environment were identified as key factors in influencing decisions not to recommend nursing as a career. There was only one study in our review in which a reasonable proportion of the public surveyed responded that they would view nursing favourably as a career (Meiring and van Wyk 2013). Earlier large sample studies from the US report more favourable public perceptions of nursing (Donelan, 2008), with nursing ranked favourably (70\% positive) as a career choice when compared to medicine ( $67 \%$ positive), but a little less favourably than teaching (74\% positive) (Donelan, 2008). This suggests that there may be difference between the United Kingdom, Middle East and the United States, with nursing perceived more favourably by the public in the United States.

\section{Implications for nursing management}

There are two paradoxical tensions evident in the discourses about the public image of nursing. Firstly, the professional self-image of nursing characterises the profession as a significant influencer and key player in public policy and healthcare leadership (Porter-O'Grady 2011). In contrast, findings of nursing research suggest that members of the general public, media and industry leaders often do not appreciate the scope and complexity of contemporary nursing. If these perceptions still persist in an information/communication rich age, it is imperative that public misconceptions about nursing and the contribution nurses make are addressed in order to avoid short-term solutions that may damage the profession and perhaps the quality of patient care. Nurse leaders must challenge negative or inadequate media coverage of nursing, and initiate a discourse to inform the public about what nursing is and about the contemporary contribution of nurses. For future populations to demand the benefits that come from expert nursing they must first understand and recognise that expertise (National Nursing Research Unit, 2015).

Our review highlights that the negative perceptions of nursing portrayed in media and film are in contrast to consumer surveys conducted in Australia, the United States and United Kingdom (Morgan 2015, Gallop 2015). These surveys repeatedly and consistently report that the general public rate nursing as the most highly ranked profession for honesty and ethical integrity. So we have a profession that is trusted and respected for it's honesty and integrity, whilst at the same time its expert knowledge base, complexity and intellectual challenge is unnoticed, if not actively denied. In a period when the delivery of health care and treatment is increasingly under scrutiny for its 
quality, effectiveness and relative cost, the understanding of nursing and the contribution nursing makes is unhelpfully out-dated and as such may limit the input and the potential benefits it could bring in the future. What is required from nurse leaders is a long-term, strategic solution that is focused on the public's engagement and interaction with the profession in a wider context than personal health/ill-health, and that goes beyond the marketing campaigns seen in the past to address recruitment crises. The narratives and images conveyed must clearly profile what it is nurses can and can't do, what nursing does and does not do, and the future of nursing (Girvin 2015). Public recognition of nursing role models in the UK are mostly limited to Florence Nightingale or, more recently, Mary Seacole - there is very little recognition of 'famous' nurses beyond these two nineteenth century women. This may well be a factor in the out-dated and sentimentalised public perception of nursing. Identifying post-Nightingale nurses who have significantly influenced the profession and the development of nursing and promoting their contribution is likely to help to shift these views.

Nurse leaders must also give attention to institutional images and narratives of, and about nursing, as these narratives are likely to influence consumer perceptions and understanding of nursing. In addition, advertising nursing accomplishments within the organisation and profiling the achievements of nurses and the contemporary role of nursing can foster a culture that values nursing as a high-image profession. Within organisations nurse leaders can do much to cultivate a positive professional image of nursing. This may include ensuring nursing services are visible to the public on organisation's web pages or brochures, and ensuring that nursing is given equitable and favourable coverage compared to medical and other services. As nurses build the public image of nursing each day through their interactions with patients, families and colleagues, nurse managers can ensure that dress codes and uniform design promote a positive professional image of nursing and, perhaps more importantly, makes it easy for patients and their relatives to distinguish nurses from other care workers.

Nurse leaders at every level should cultivate relationships with local and national media and actively seek opportunities to portray nursing work, research and achievements in the media on a regular basis. Developing expertise in the use of social media for professional 
purposes can increase the reach and influence of nurses who aspire to lead outside of traditional organisational and hierarchical contexts.

Although nursing research has done much to identify the disparate public portrayal and public perception of nursing, it has done to little to address it. To date, few studies have employed valid and reliable instruments to examine public perceptions, and the majority have employed convenience samples or secondary data analysis of document and media images. The continued utilisation of media and film as sources of information about public perceptions of nursing risks skewing professional discourses. Future research should give attention to issues of validity and reliability and designing measures that provide a more comprehensive and nuanced examination of public attitudes and perceptions.

\section{Limitations}

A number of limitations apply to this review. No high level evidence studies (Level II: a randomised controlled trial) were located and risk of confounding was present in the majority of quantitative studies. A further limitation is that a number of the studies were of low quality and the majority of survey studies employed instruments that did not have established validity and reliability. Furthermore, a number of the qualitative studies failed to adequately report data analysis methodology or researcher reflexivity. The poor heterogeneity amongst the studies also limits cross study comparison. These issues may limit the generalisability of the review results. However, the strength of the review is that it brings together a collection of contemporary studies in an appraisal that sheds new insights into the topic.

\section{Conclusion}

Our analysis has highlighted some positive public perceptions and representations of nursing. It has also highlighted the continued negative representation of nursing in newsprint, social media and film, and the influence of key individuals (such as schools careers counsellors) in sustaining outdated and limiting images of nursing, which undermine confidence in nursing as a career choice. A long-term, strategic solution is required which focuses on public engagement and interaction with the profession in a wider context than personal health/ill-health, and that go beyond the marketing campaigns seen in the past to 
address recruitment crises. The authors will be addressing such an approach in their followup work.

\section{References}

Allnutt J. Allnutt N. McMaster R. O'Connell J. Middleton S. Hillege S. Della P.R. Gardner G.E. \& Gardner A. (2010) Clients' understanding of the role of nurse practitioners. Australian Health Review 34(1), 59-65.

Ben Natan M. \& Becker F. (2010) Israelis' perceived motivation for choosing a nursing career. Nurse Education Today 30(4), 308-13.

Ben Natan M. Dmitriev Y. Shubovich O. \& Sharon I. (2013) Views of the Israeli public on expanding the authority of nurses. Journal of Nursing Management 21(2), 351-358.

Boyle D.A. (2010) The invisibility of nursing: implications from an analysis of national cancer intstitute-designated comprehesnive cancer center web sites. Oncology Nursing Forum 37(2), E75-83.

Brideson G. Willis E. Mayner L. Chamberlain D.J. (2015 early view) Images of flight nursing in Australia: a study using institutional ethnography. Nursing \& Heatlh Science doi .1111/nhs. 12225

Cho S.H. Jung S.Y. \& Jang S. (2010) Who enters nursing schools and why do they choose nursing? a comparison with female non nursing students using longitudinal data. Nurse Education Today 30, 180-186.

Clow K.A. \& Ricciardelli R. (2011) Women and men in conflicting social roles: implications from social psychological research. Social Issues and Policy Review 5(1), 191-226.

Donelan K. Buerhaus P. DesRoches C. Dittus R. \& Dutwin D. (2008) Public perceptions of nursing careers: the influence of the media and nursing shortages. Nursing Economics 26(3), 144.

Donley R. (2005) Challenges for nursing in the 21st century. Nursing Economics 23(6) 312318.Eagly, A.H. \& Karau, S.J. (2002) Role congruity theory of prejudice toward female leaders. Psychological review 109(3), 573.

Francis R. (2010) Independent Inquiry into care provided by Mid Staffordshire NHS Foundations. Healthcare Commission

Gallop. (2015) Americans rate nurses highest on honesty, ethical standards.

Gillett K. (2014) Nostalgic constructions of nurse education in British national newspapers. Journal of Advanced nursing 70(11), 2495-2505.

Girvin J. (2015) Editorial: The public understanding of nursing-time for a step change? Journal of Clinical Nursing 24 (23-24) 3341-3342.

Harbour R. \& Miller J. (2001) A new system for grading recommendations in evidence based guidelines. BMJ: British Medical Journal 323(7308), 334.

Health Education England. (2015) Raising the bar. Shape of caring: a review of the future education and training of Registred Nurses.

Hoeve Y.T. Jansen, G. \& Roodbol P. (2014) The nursing profession: public image, selfconcept and professional identity. A discussion paper. Journal of advanced nursing 70(2), 295-309.

Hutchinson M. \& Jackson D. (2014) Troubling fragments and small stories: an analysis of public commentary on nursing through a web blog. Collegian 21(2), 81-88.

Institute of Medicine. (2010) The future of nursing: leading change, advancing health. Retrieved from http://books.nap.edu/openbook.php?record_it=12956\&page=R1. 
Jackson D. Hutchinson M. Luck L. \& Wilkes L. (2013) Mosaic of verbal abuse experienced by nurses in their everyday work. Journal of advanced nursing 69(9), 2066-2075.

Johnson M. Cowin L.S. Wilson I. \& Young H. (2012) Professional identity and nursing: contemporary theoretical developments and future research challenges. International Nursing Review 59, 562-569.

Keçeci A. Çelik Durmuş S., Oruç D. \& Öner Kapisiz Ö. (2014) The Society's View of Nursing in Turkey. Hospital topics 92(2), 36-43.

Kelly J. Fealy G.M. \& Watson R. (2012) The image of you: constructing nursing identities in YouTube. Journal of Advanced Nursing 68(8), 1804-1813.

Keogh B. (2013) Review into the Quality of Care and Treatment Provided By 14 Hospital Trusts in England: Overview Report. Available at: http://www.nhs.uk/NHSEngland/bruce-keogh-review/Docment/outcomes/Keoghreview-final-report-pdf (accessed 7 July 2015).

Khoury C.M.Blizzard R., Moore L.W. \& Hassmiller S. (2011) Nursing leadership from bedside to boardroom: a gallup national survey of opinion leaders. Journal of Nursing administration, 41(7/8), 299-305.

Lasiter S. \& McLennon S. M. (2015). Nursing Professional Capital: A Qualitative Analysis. Journal of Nursing Administration 45(2), 107-112. http://dx.doi.org/10.1097/NNA.0000000000000164

Lloyd L. Banerjee A., Harrington C. F. Jacobsen F. \& Szebehely M. (2014) It is a scandal! Comparing the causes and consequences of nursing home media scandals in five countries. International Journal of Sociology and Social Policy 34(1/2), 2-18.

Meiring A. \& Van Wyk N.C. (2013) The image of nurses and nursing as perceived by the South African public. Africa Journal of Nursing and Midwifery 15(2), 3-15.

Miller E.A. Tyler D.A., Rozanova J. \& Mor,V. (2012) National newspaper portrayal of US nursing homes: periodic treatment of topic and tone. Milbank Quarterly 90(4), 725761.

Miller K. \& Cummings G. (2009) Gifted and talented students' career aspirations and influences: a systematic review of literature. International Journal of Nursing Education Scholarship 6(1).

Morgan R. (2015) Roy Morgan image of professional survey - 2015.

Morris Thompson T. Shepherd J. Plata R. \& Marks-Maran D.I. (2011) Diversity, fulfilment and privilege: the image of nursing. Journal of Nursing Management 19(5), 683-692.

Natan M.B. \& Becker F. (2010) Israelis' perceived motivation for choosing a nursing career. Nurse education today, 30(4), 308-313.

National Nursing Research Unit (2015). Florence Nightingale School of Nursing and Midwifery King's College London. Retrieved from: http://www.kcl.ac.uk/nursing/research/nnru/index.aspx

Neilson G.R. \& McNall J. (2013) The negative influence of significant others on high academic achieving school pupils' choice of nursing as a career. Nurse education today, 33(3), 205-209.

Neilson G.R. \& McNally J.G. (2010) Not choosing nursing: Work experience and career choice of high academic achieving school leavers. Nurse education today, 30(1), 914.

Norman K. (2015) The image of community nursing: implications for future student nurse recruitment. Br J Community Nurs, 20(1), 12-8.

Porter-O'Grady T. (2011) Future of nursing special: leadership at all levels. Nursing Management 42(5) 32-37.

Pace R. Pluye P. Bartlett G., Macaulay,A.C., Salsberg J.Jagosh J. \& Seller R. (2012) Testing the reliability and efficiency of the pilot Mixed Methods Appraisal Tool (MMAT) for 
systematic mixed studies review. International journal of nursing studie, 49(1), 4753.

Poikkeus T. Numminen O. Su Honen R. \& Leino-Kilp H. (2014) A mixed-method systematic review: support for ethical competence of nurses. Journal of Advanced Nursing 70(2), 256-271.

Rezaei-Adaryani M. Salsali M. \& Mohammadi E. (2012) Nursing image: An evolutionary concept analysis. Contemporary Nurse 43(1), 81-89.

Shields L. (2012) A personal essay on the role of the nurse. Contemporary Nurse, 43, 213 218.

Soman R. Karmaliani R. Mc Farlane J. Asad N. \& Hiran, S. (2015) Sexual Harassment towards Nurses in Pakistan: are we Safe? International Journal of Nursing Education, 7(2), 286-289.

Spector P.E. Zhou Z.E. \& Che X.X. (2014) Nurse exposure to physical and nonphysical violence, bullying, and sexual harassment: a quantitative review. International journal of nursing studies, 51(1), 72-84.

Stanley D.J. (2013) Celluloid angels: a research study of nurses in feature films 1900-2007. Journal of Advanced Nursing 68(11), 84-95.

Takase M. \& Kershaw E. (2002) Does the public image of nursing matter? Journal of Profssional Nursing 18(4), 196-205.

Van Tonder A. Van Wyk N.C. (2011) The perceptions of visitors at acute care units in two private hospitals in Gauteng, South Africa regarding the image of nurses and nursing. International Journal of Nursing and Midwifery, 3(9) 128-138.

Wilson P.M. Brooks F. Procter S. \& Kendall S. (2012) The nursing contribution to chronic disease management: a case of public expectation? Qualitative findings from a multiple case study design in England and Wales. International journal of nursing studies 49(1), 2-14.

Willis G.P. (2015) Raising the Bar. Shape of Caring: A Review of the Future Education and Training of Registered Nurses and Care Assistants. Health Education England, London

Zhuge Y. Kaufman J. Simeone D.M. Chen H. \& Velazquez O.C. (2011) Is there still a glass ceiling for women in academic surgery? Annals of surgery, 253(4), 637-643.

Van Zyl G. \& Christofides N. (2014) International Nurses Day and press coverage in South Africa. International nursing review 61(2), 186-193. 
Figure 1 Search strategy

Search terms and Keywords identified

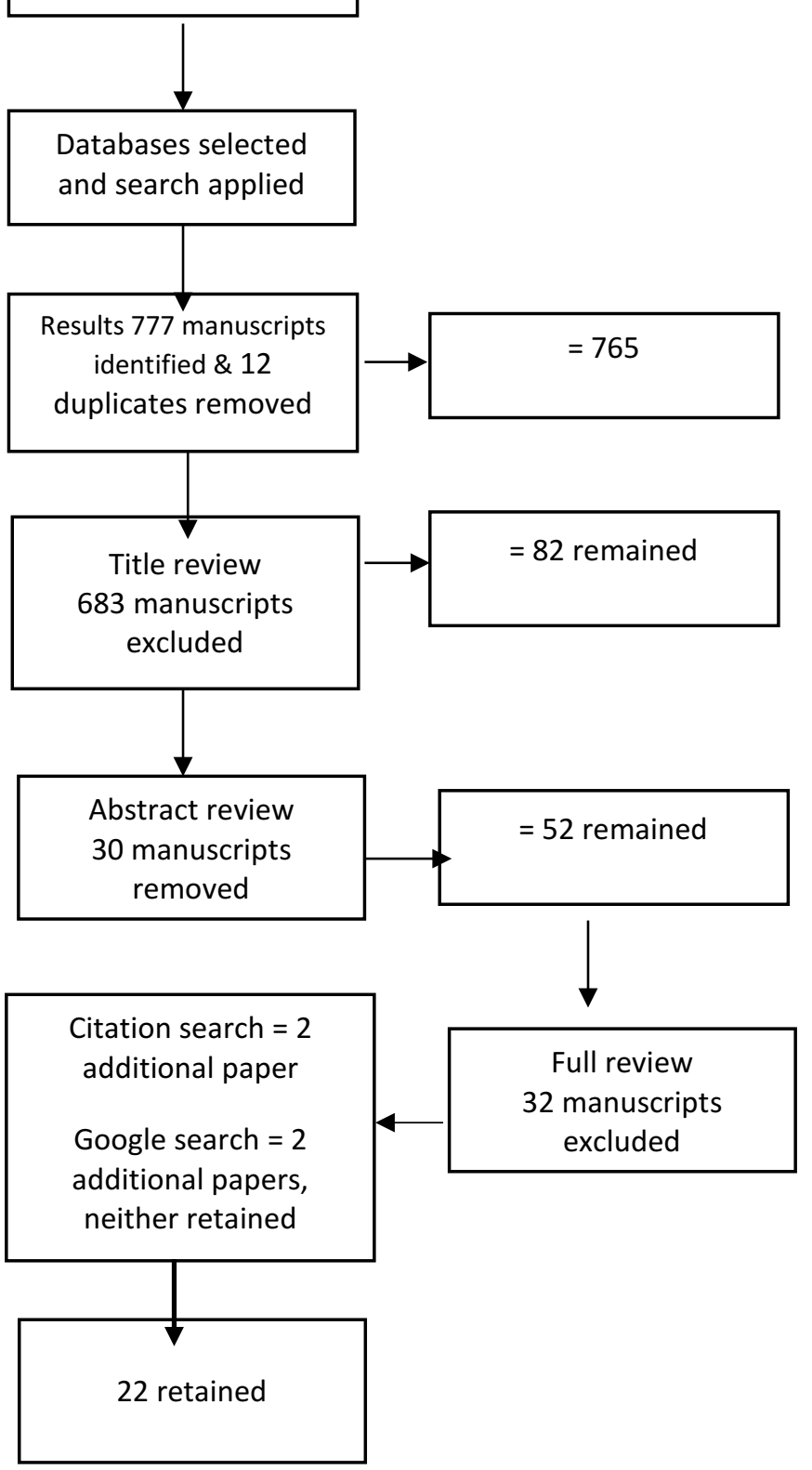


Table 1: Summary of initial database search results

\begin{tabular}{|c|c|c|}
\hline Search terms & Database & Initial results \\
\hline \multirow{4}{*}{$\begin{array}{l}\text { Initial primary search terms used were: public- } \\
\text { understanding* OR public-knowledge* AND } \\
\text { nurs*, with these extended to include public- } \\
\text { perceive* OR public-perception* OR public- } \\
\text { view* OR public-thought* OR public-opinion* } \\
\text { OR public-image* OR public-concept* OR } \\
\text { public-attitude* AND nurs*. }\end{array}$} & CINAHL & 36 \\
\hline & $\begin{array}{l}\text { British Nursing Index } \\
\text { (BNI) }\end{array}$ & 386 \\
\hline & PubMed & 272 \\
\hline & Pyschlnfo & 83 \\
\hline
\end{tabular}


Table 2: Details of studies included in the review

\begin{tabular}{|c|c|c|c|c|}
\hline Author & Setting & Sample & Design & Findings \\
\hline Alnutt, et al, 2010 & Australia & $\begin{array}{l}129 \text { clients of Nurse } \\
\text { Practitioners }\end{array}$ & $\begin{array}{l}\text { Quantitative survey of clients asked } \\
\text { to rate satisfaction and } \\
\text { understanding of Nurse } \\
\text { Practitioners following consultation }\end{array}$ & $\begin{array}{l}63 \% \text { accurately identified nurse consulted as } \\
\text { an NP. } 27 \% \text { did not differentiate Nurse } \\
\text { Practitioners from doctor or other nurse with } \\
\text { regard to care they can provide. } 77 \% \text { believed } \\
\text { any nurse in Australia can call themselves an } \\
\text { Nurse Practitioners. Less than half were aware } \\
\text { of specialist functions NPs can provide }\end{array}$ \\
\hline Boyle, D.A., 2010 & $\begin{array}{l}\text { United } \\
\text { States }\end{array}$ & $\begin{array}{l}40 \text { websites of designated } \\
\text { Comprehensive Cancer } \\
\text { Centers }\end{array}$ & $\begin{array}{l}\text { Qualitative content analysis of } \\
\text { nursing representation on public } \\
\text { web sites }\end{array}$ & $\begin{array}{l}\text { Only } 2 \text { of the } 40 \text { Comprehensive Cancer } \\
\text { Centers revealed broad representation of } \\
\text { nursing throughout their Web site. Nearly } 63 \% \\
\text { of Comprehensive Cancer Centers Web sites } \\
\text { had no or minimal content about nursing. }\end{array}$ \\
\hline Ben Natan., 2010 & Israel & $\begin{array}{l}\text { Adults recruited at a } \\
\text { social-health event in } \\
2008(n=309)\end{array}$ & $\begin{array}{l}\text { Cross sectional survey } \\
\text { Previously validated instrument }\end{array}$ & $\begin{array}{l}\text { Public asked to rate perceptions of their ideal } \\
\text { career and perceptions of nursing as a career, } \\
\text { image of nursing and job opportunities in } \\
\text { nursing. } \\
8 \% \text { of respondents expressed interest in } \\
\text { studying nursing. Those who held a more } \\
\text { positive image of nursing were confident } \\
\text { about finding a job in nursing. The ideal job } \\
\text { rated more highly as challenging when } \\
\text { compared to nursing (Ideal } M 4.27 \text { Nursing } M \\
4.05, t 3.74 P=0.00 \text { ); Nursing rated more } \\
\text { highly on helping people (Ideal job } M 318 \text {; } \\
\text { Nursing } M 4.33 t-4.84, P=0.00 \text { ). }\end{array}$ \\
\hline Gillett, K. 2014 & $\begin{array}{l}\text { United } \\
\text { Kingdom }\end{array}$ & $\begin{array}{l}\text { British Newspapers }(n=11) \\
\text { for the period } 1999- \\
2012.23 \text { articles included } \\
\text { in the sample. }\end{array}$ & $\begin{array}{l}\text { Critical discourse analysis of } \\
\text { newspaper articles focusing upon } \\
\text { the increased academic level of } \\
\text { nurse education in the United } \\
\text { KIngdom }\end{array}$ & $\begin{array}{l}\text { Negative articles = } 61 \% \text {; Neutral = } 17.9 \% \text {; } \\
\text { Positive = } 20 \% \text {. Caring or educated } \\
\text { dichotomy. Negative discourse on nurse } \\
\text { education. } \\
\text { Nostalgic discourse on the "golden era of } \\
\text { nursing" and turning back the clock. }\end{array}$ \\
\hline $\begin{array}{l}\text { Hutchinson M, } \\
\text { Jackson D. } 2014\end{array}$ & England & $\begin{array}{l}80 \text { web blog postings from } \\
52 \\
\text { Individuals }\end{array}$ & $\begin{array}{l}\text { Qualitative Content analysis of } \\
\text { public web blogs that were in } \\
\text { response to media story 'Don't } \\
\text { believe the } \\
\text { Horror stories about nurses' }\end{array}$ & $\begin{array}{l}\text { Major categories related to recounted } \\
\text { incidence of nursing care that were } \\
\text { characterised as indifferent. Sub-categories i) } \\
\text { thoughtless and careless care ii) unresponsive } \\
\text { care iii) Ignored, iv) hostile defence of } \\
\text { indifference. }\end{array}$ \\
\hline $\begin{array}{l}\text { Van Zyl, G.S., } \\
\text { Christofides, N.J., } \\
2014\end{array}$ & South Africa & $\begin{array}{l}242 \text { articles in } 95 \\
\text { publications for the period } \\
\text { January-April and May- } \\
\text { June } 2010\end{array}$ & $\begin{array}{l}\text { Qualitative Content analysis and } \\
\text { statistical comparative analysis of } \\
\text { newspaper articles relating to } \\
\text { International Nurses Day }\end{array}$ & $\begin{array}{l}\text { Of the articles, 50\% positive about nursing, } \\
44 \% \text { negative. Main topics nursing as a } \\
\text { profession; neglect and unprofessionalism; } \\
\text { academic nursing; strikes/protests; labour } \\
\text { issues. }\end{array}$ \\
\hline $\begin{array}{l}\text { Keçeci A, Celik } \\
\text { Durmuş S, Oruç } \\
\text { D, Öner Kapisiz Ö. } \\
2014\end{array}$ & Turkey & $\begin{array}{l}\text { Stratified sample of } 458 \\
\text { residents in a district of } \\
\text { Turkey }\end{array}$ & Face to face questionnaire & $\begin{array}{l}\text { Majority }(70.2 \%) \text { stated that nurses provided } \\
\text { patient care, while } 18.1 \%(71) \text { thought nurses } \\
\text { were assistants to doctors; } 2.6 \% \text { perceived } \\
\text { nurses as angels or saviours; } 2 \% \text { viewed } \\
\text { nurses as sex appeal; } 6.4 \% \text { thought nurses }\end{array}$ \\
\hline
\end{tabular}




\begin{tabular}{|c|c|c|c|c|}
\hline & & & & were arrogant or bad tempered. \\
\hline $\begin{array}{l}\text { Kelly, J., Gerard } \\
\text { M. Fealy, G.M., } \\
\text { Watson, R.,2012 }\end{array}$ & International & $\begin{array}{l}\text { Purposive sample of the } \\
\text { ten most viewed video } \\
\text { clips on nursing accessed } \\
\text { on two days in July } 2010 \text {. }\end{array}$ & $\begin{array}{l}\text { Critical discourse analysis of the } \\
\text { construction of nursing identify in } \\
\text { the Web } 2.0 \text { site YouTube }\end{array}$ & $\begin{array}{l}\text { Four of the ten selected video clips presented } \\
\text { images of educated, smart and technically } \\
\text { skilled nurses. Three distinct nursing identity } \\
\text { types, namely nurse as 'a skilled knower and } \\
\text { doer', nurse as 'a sexual plaything' and nurse } \\
\text { as 'a witless incompetent' individual. }\end{array}$ \\
\hline Khoury et al, 2011 & $\begin{array}{l}\text { United } \\
\text { States }\end{array}$ & $\begin{array}{l}\text { Cross sectional survey of } \\
\text { public and private sector } \\
\text { leaders (university, } \\
\text { insurance, corporate, } \\
\text { health service, } \\
\text { government and industry) }\end{array}$ & $\begin{array}{l}\text { Descriptive quantitative analysis of } \\
\text { telephone interview }(n=1504) \text { data }\end{array}$ & $\begin{array}{l}\text { Leaders reported nurses degree of influence } \\
\text { on health reform varied from } 14 \% \text { - } 23 \% \text {. A } \\
\text { little over half stated nurses had a great deal } \\
\text { of influence on averting errors and improving } \\
\text { safety and quality. Quality of the work } \\
\text { environment identified as the major factor } \\
\text { influencing nursing recruitment. Media } \\
\text { depiction of nursing and stereotypes, along } \\
\text { with education seen as major barriers to } \\
\text { nursing leadership }\end{array}$ \\
\hline $\begin{array}{l}\text { Van Tonder and } \\
\text { Neltjjie, } 2011\end{array}$ & South Africa & $\begin{array}{l}\text { Convenience survey of } \\
\text { hospital visitors }\end{array}$ & 110 adult visitors & $\begin{array}{l}\text { The majority of participants (95\%) either } \\
\text { strongly agreed or agreed ( } 51 \%) \text { that nurses } \\
\text { are caring and understanding. } 98 \% \text { agreed or } \\
\text { strongly agreed that nursing is a profession } \\
\text { that is not secondary to doctors. } 54 \% \\
\text { disagreed that nurses are considered to have } \\
\text { sex appeal. }\end{array}$ \\
\hline Miller, Et al., 2012 & $\begin{array}{l}\text { United } \\
\text { States }\end{array}$ & $\begin{array}{l}\text { Employed the LexisNexis } \\
\text { database to identify } \\
\text { articles pertaining to } \\
\text { nursing homes. }\end{array}$ & $\begin{array}{l}\text { Structured content analysis of } \\
1,704 \text { articles followed by } \\
\text { comparative statistical analysis }\end{array}$ & $\begin{array}{l}\text { Most were negative ( } 45.1 \%) \text { or neutral } \\
(37.0 \%) \text { in tone, and very few were positive } \\
(9.6 \%) \text { or mixed ( } 8.3 \%) . \text { Most frequent } \\
\text { themes were quality, financing and } \\
\text { negligence. }\end{array}$ \\
\hline Wilson, et al.., & England & $\begin{array}{l}\text { Census or random survey } \\
\text { of adult and child service } \\
\text { users ( } n=1635 \text { ) and } \\
\text { interview }(n=84) \text { or focus } \\
\text { group }(n=6)\end{array}$ & Qualitative content analysis & $\begin{array}{l}\text { Nurses contribution to chronic disease } \\
\text { management was valued by some service } \\
\text { users, others were unclear of the scope of } \\
\text { nurse specialist roles, and positioned nurses } \\
\text { as apprentices to doctors. Some were not } \\
\text { familiar with the role of nurses in primary } \\
\text { health care settings. }\end{array}$ \\
\hline Ben Natan et al., & Israel & $\begin{array}{l}\text { Cross sectional survey of } \\
\text { adults }(n=200)\end{array}$ & Quantitative comparative analysis & $\begin{array}{l}67 \% \text { of respondents supported expanded role } \\
\text { for nurses to undertake procedure such as } \\
\text { intravenous drug administration ordering } \\
\text { blood and blood tests. }\end{array}$ \\
\hline $\begin{array}{l}\text { Meiring, A., van } \\
\text { Wyk, N.C., } 2013\end{array}$ & South Africa & $\begin{array}{l}\text { Convenience sample of } \\
1000 \text { adults from five of } \\
\text { the nine provinces. } \\
\text { Response } 776\end{array}$ & $\begin{array}{l}\text { Survey that had previously been } \\
\text { used in studies in the United } \\
\text { KIngdom and South Africa }\end{array}$ & $\begin{array}{l}\text { Most respondents viewed nurses as } \\
\text { extremely hardworking }(80.0 \% ; n=621) \text { and } \\
\text { caring and understanding }(78.2 \% ; n=607) \text {. } \\
\text { Notwithstanding the positive comments } \\
\text { about nurses, only } 43.6 \% \text { ( } n=338 \text { ) of the } \\
\text { respondents indicated that they would want }\end{array}$ \\
\hline
\end{tabular}




\begin{tabular}{|c|c|c|c|c|}
\hline & & & & their children to become nurses. \\
\hline $\begin{array}{l}\text { Neilson, G.R., } \\
\text { McNally, J.G., } \\
2010\end{array}$ & Scotland & $\begin{array}{l}\text { School students in } 5^{\text {th }} \text { and } \\
6^{\text {th }}(n=20)\end{array}$ & $\begin{array}{l}\text { Qualitative interviews with } 20 \text { high } \\
\text { academic achieving 5th and 6th } \\
\text { year school students that were } \\
\text { drawn from a larger survey study of } \\
\text { students }(n=1062) \text {. }\end{array}$ & $\begin{array}{l}\text { School students experienced negative work } \\
\text { experience placements in nursing, this } \\
\text { influenced their perceptions about the } \\
\text { suitability of nursing as a career }\end{array}$ \\
\hline $\begin{array}{l}\text { Neilson, G.R., } \\
\text { McNally, J.G., } \\
2013\end{array}$ & Scotland & $\begin{array}{l}\text { Twenty } 5^{\text {th }} \text { and } 6^{\text {th }} \text { year } \\
\text { school students }\end{array}$ & $\begin{array}{l}\text { Qualitative interviews with } 20 \text { high } \\
\text { academic achieving } 5 \text { th and } 6 \text { th } \\
\text { year school students that were } \\
\text { drawn from a larger survey study of } \\
\text { students ( } n=1062) \text {. }\end{array}$ & $\begin{array}{l}\text { Guidance and career officers advising against } \\
\text { nursing as a career choice } \\
\text { Nursing on par with hairdressing or office } \\
\text { work } \\
\text { Two of the sample said that their career } \\
\text { choice was their decision, influenced by } \\
\text { family }\end{array}$ \\
\hline Norman, K.M., & England & $\begin{array}{l}\text { Four schools, } 40 \text { year } 11 \\
\text { high school students, } 10 \\
\text { from each school ( } 5 \text { male } \\
\text { and } 5 \text { female) }\end{array}$ & $\begin{array}{l}\text { Qualitative interviews with } \\
\text { students focusing upon } \\
\text { perceptions about community } \\
\text { nursing as a career }\end{array}$ & $\begin{array}{l}\text { Themes identified on the image of nursing } \\
\text { Nursing as a profession } \\
\text { Social, educational and political influence }\end{array}$ \\
\hline Stanley, D., 2012 & International & $\begin{array}{l}\text { For the period } 1900 \text { to } \\
2007,13 \text { western feature } \\
\text { films portraying images of } \\
\text { male nurses }\end{array}$ & $\begin{array}{l}\text { Interpretive, qualitative } \\
\text { methodology }\end{array}$ & $\begin{array}{l}\text { Male nurses were portrayed negatively, as } \\
\text { effeminate, homosexual, homicidal, corrupt } \\
\text { or incompetent. Few showed them as } \\
\text { clinically competent. }\end{array}$ \\
\hline $\begin{array}{l}\text { Morris- } \\
\text { Thompson, T., } \\
\text { Shepherd, J., } \\
\text { Plata, R., Marks- } \\
\text { Maran, D., } 2011\end{array}$ & England & $\begin{array}{l}\text { Data were collected (2009) } \\
\text { in two stages. Stage } 1 \\
\text { from nurses and stage two } \\
\text { from } 159 \text { non-nurses. }\end{array}$ & $\begin{array}{l}\text { Stage two: Qualitative focus } \\
\text { groups and interviews with } \\
\text { members of the public. } \\
\text { Focus groups and four in-depth } \\
\text { interviews with careers teachers, } \\
\text { six interviews with journalists, } 10 \\
\text { interviews with doctors, one focus } \\
\text { group with mature career } \\
\text { switchers, one focus group with } \\
\text { graduates, four focus groups with } \\
\text { parents and six focus groups with } \\
\text { school children. In addition, } 51 \\
\text { interviews were held with children } \\
\text { aged 7-17 years. }\end{array}$ & $\begin{array}{l}\text { Positive perception of the public about } \\
\text { nursing included that nursing is difficult and } \\
\text { nasty work but of real value. } \\
\text { Nurses are underpaid and make real } \\
\text { sacrifices. } \\
\text { Nurses are people of principle. } \\
\text { Nurses care and try their best against many } \\
\text { odds. }\end{array}$ \\
\hline $\begin{array}{l}\text { Rezaeia-Daryani } \\
\text { et al } 2012\end{array}$ & International & $\begin{array}{l}\text { Literature search } 1980- \\
2011 \\
\text { (n=106 papers) }\end{array}$ & Concept analysis of literature & $\begin{array}{l}\text { Media, invisibility, clothing style, nurses' } \\
\text { behaviours, gender issues, and professional } \\
\text { organizations are the most important } \\
\text { antecedents of the concept }\end{array}$ \\
\hline Brideson, 2015 & Australia & $\begin{array}{l}\text { Review of popular } \\
\text { literature sources from } \\
\text { the early 1940s through to }\end{array}$ & Qualitative institutional e & $\begin{array}{l}\text { Image presented of flight nurses as } \\
\text { adventurous; much of the material reviewed } \\
\text { in this study was published during periods of }\end{array}$ \\
\hline
\end{tabular}




\begin{tabular}{|l|l|l|l|l|}
\hline & & the present. & ethnography & $\begin{array}{l}\text { war - emphasis upon recruiting woman to } \\
\text { take up the role. }\end{array}$ \\
\hline $\begin{array}{l}\text { Lasiter S, } \\
\text { SM.2015 }\end{array}$ & United & $\begin{array}{l}\text { Ten semi-structured } \\
\text { interviews (2008) with } \\
\text { older adults' about } \\
\text { experiences of feeling safe } \\
\text { in an intensive care unit } \\
\text { (ICU). }\end{array}$ & $\begin{array}{l}\text { Secondary content analysis of } \\
\text { interview data }\end{array}$ & $\begin{array}{l}\text { Two themes provided evidence for positive } \\
\text { public regard of nurses. Three subcategories i) } \\
\text { taking their word for it, ii) they know just } \\
\text { what to do, and iii) I know they watch you, }\end{array}$ \\
\hline
\end{tabular}


Table 3: Summary of quality review of included studies

\begin{tabular}{|c|c|c|c|}
\hline \multirow[t]{2}{*}{ Criteria } & \multicolumn{3}{|c|}{ No. of studies } \\
\hline & Yes & No & N/A \\
\hline \multicolumn{4}{|l|}{ Quantitative studies } \\
\hline Appropriate sequence generation/randomization & 1 & 9 & - \\
\hline Allocation concealment and/or blinding & - & - & 10 \\
\hline Complete outcome data and low withdrawal & - & - & 10 \\
\hline Recruitment in a way that minimized confounders & 3 & 9 & - \\
\hline Intervention and control group comparable & - & - & 10 \\
\hline Evidence of an absence of contamination & - & - & 10 \\
\hline Complete outcome date/acceptable response rate & 1 & - & 9 \\
\hline Appropriate sampling and sample & 8 & 2 & - \\
\hline Justification of measurement (valid/standard) & $2^{*}$ & $8^{* *}$ & - \\
\hline Acceptable response rate & 9 & 1 & - \\
\hline \multicolumn{4}{|l|}{ Qualitative studies } \\
\hline Qualitative objective or question & 12 & 0 & - \\
\hline Appropriate qualitative approach or method & 12 & 0 & - \\
\hline Description of the context & 11 & 1 & - \\
\hline Description of participants and sampling & 9 & 3 & - \\
\hline Description of data collection and analysis & 5 & 7 & - \\
\hline Discussion of researchers' reflexivity & 5 & 7 & - \\
\hline \multicolumn{4}{|l|}{ Mixed method studies } \\
\hline Appropriate sampling and sample & 1 & 0 & \\
\hline Justification of measurement (valid/standard) & 0 & 0 & $1 * * *$ \\
\hline Acceptable response rate & 0 & 0 & $1^{* * *}$ \\
\hline $\begin{array}{l}\text { Combination of qualitative and quantitative data collection- } \\
\text { analysis techniques or procedures }\end{array}$ & 1 & 0 & \\
\hline Justification of the mixed methods design & 1 & 0 & \\
\hline \multicolumn{4}{|l|}{ Justification of the mixed methods design } \\
\hline From The validated Mixed Methods Appraisal Tool (MMAT) (Pace, P & le et a & & \\
\hline
\end{tabular}

Table 4: Public perceptions according to source

Image of nursing

\begin{tabular}{cccc}
\hline Source & Mixed & Positive & Negative \\
& No. & No. & No. \\
\hline
\end{tabular}


Service users

General public

Industry leaders

School children \& career

Counsellors

Media and film
*

$* * * * *$

*

*

**

$* * *$ 
